ORNL/TM-2003/258

\title{
LITERATURE REVIEW FOR THE BASELINE KNOWLEDGE ASSESSMENT \\ OF THE \\ HYDROGEN, FUEL CELLS, AND INFRASTRUCTURE TECHNOLOGIES PROGRAM
}

\author{
Tykey Truett \\ Center for Transportation Analysis \\ Oak Ridge National Laboratory
}

October 2003

\author{
Prepared by the \\ OAK RIDGE NATIONAL LABORATORY \\ Oak Ridge, Tennessee 37831-6073 \\ Managed by \\ UT-BATTELLE, LLC \\ For the \\ U.S. DEPARTMENT OF ENERGY \\ Under contract No. DE-AC05-00OR22725
}

Prepared for the

Hydrogen, Fuel Cells, and Infrastructure Technologies Program

Office of Energy Efficiency and Renewable Energy

U.S. DEPARTMENT OF ENERGY

Washington, D.C. 


\section{CONTENTS}

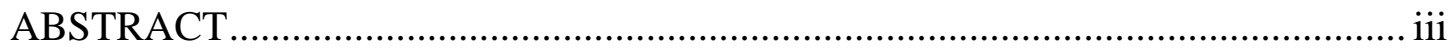

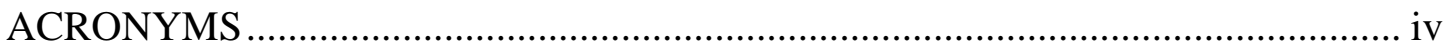

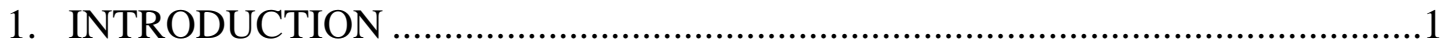

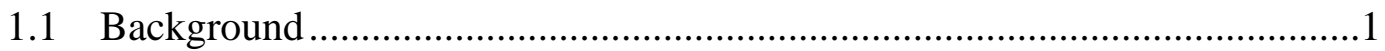

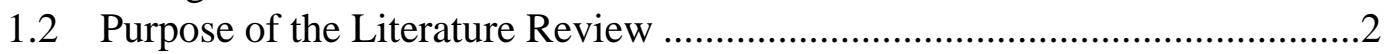

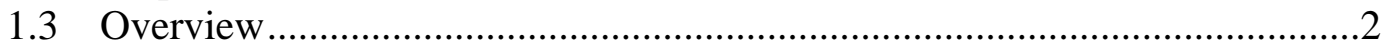

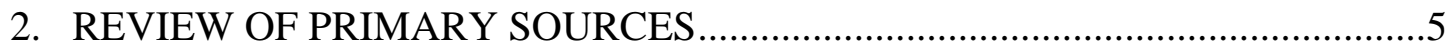

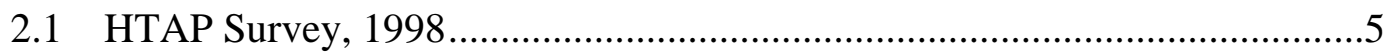

2.1.1 Outreach and Communication .............................................................

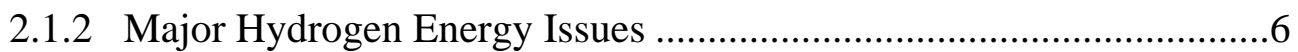

2.2 European Commission Accept H2 Surveys, 1998 ……………………….......

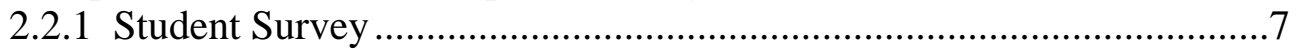

2.2.2 Survey of Bus Passengers ................................................................

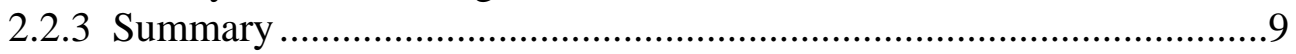

2.2.4 Further Research .............................................................................

2.3 Breakthrough Technologies Survey, 2002 …………..................................10

2.4 Rocky Mountain Poll, 2002 .......................................................................11

2.5 European Commission EUROBAROMETER Survey, 2002 ….....................13

2.5.1 General Perceptions ......................................................................13

2.5.2 Information .................................................................................13

2.5.3 Perceptions of the Future .................................................................13

2.5.4 Behavior of the Public ..................................................................14

2.6 Transportation Energy Surveys, 2002 and 2003............................................14

2.6.1 Transportation Energy Survey Data Book 1.1 …................................14

2.6.2 Consumer Views on Transportation and Energy ...............................15

2.7 Millennium Cell Survey, 2003.....................................................................16

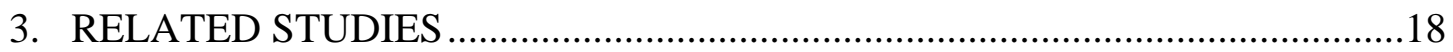

3.1 California Fuel Cell Partnership ................................................................18

3.2 H2CARSBIZ .......................................................................................19

3.3 RKS Distributed Resources Studies..........................................................19

3.3.1 Household Surveys ......................................................................19

3.3.2 Business Surveys …………….......................................................19

3.4 Additional Studies Documented by Accept H2 ...........................................20

3.5 Gallop Organization..................................................................................21

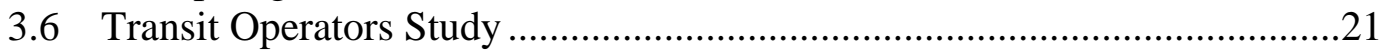

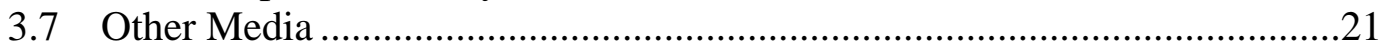

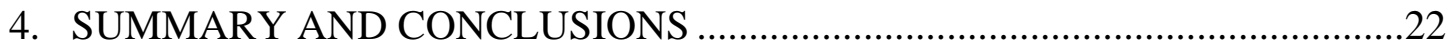

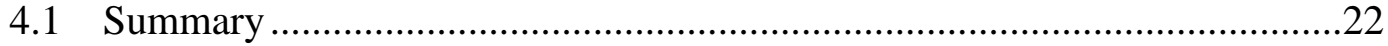

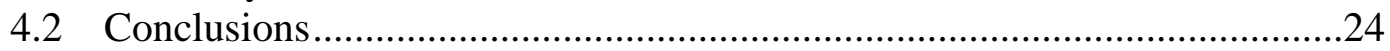


4.2.1 General Public...................................................................................25

4.2.2 Potential Large Users (Industry) .......................................................25

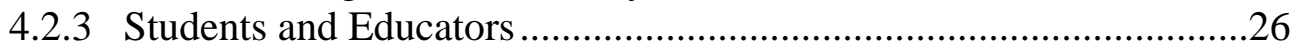

4.2.4 State and Local Agencies..............................................................26

4.2.5 HFCIT Surveys and Other Organizations ............................................27

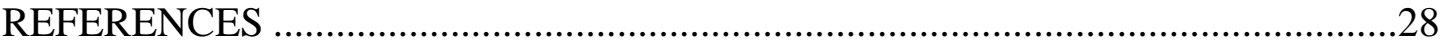

$\underline{\text { Table }}$

\section{LIST OF TABLES AND FIGURES}

1 Ratings for HTAP survey question on outreach and communication efforts .................6

2 Ratings for HTAP survey question on major hydrogen energy issues ...........................6

3 Response to Rocky Mountain Poll question on willingness to purchase hydrogen-fueled passenger vehicle.............................................................................12

4 Response to Millennium Cell survey question on factors influencing decisions to try a new fuel technology...................................................................................16

5 Overview and comparison of primary sources ………..............................................23

Figure

1 Responses to Rocky Mountain Poll question on how to reduce U.S. dependence on foreign oil...........................................................................................

2 Willingness of Americans to try a new hydrogen-based technology to fuel vehicles 


\begin{abstract}
The purpose of the Hydrogen, Fuel Cells, and Infrastructure Technologies (HFCIT) Program Baseline Knowledge Assessment is to measure the current level of awareness and understanding of hydrogen and fuel cell technologies and the hydrogen economy. This information will be an asset to the HFCIT program in formulating an overall education plan. It will also provide a baseline for comparison with future knowledge and opinion surveys.

To assess the current understanding and establish the baseline, the HFCIT program plans to conduct scientific surveys of four target audience groups - the general public, the educational community, governmental agencies, and potential large users.

The purpose of the literature review is to examine the literature and summarize the results of surveys that have been conducted in the recent past concerning the existing knowledge and attitudes toward hydrogen. This literature review covers both scientific and, to a lesser extent, non-scientific polls.

Seven primary data sources were reviewed, two of which were studies based in Europe. Studies involved both closed-end and open-end questions; surveys varied in length from three questions to multi-page interviews. Populations involved in the studies were primarily adults, although one study involved students. The number of participants ranged from 13 to over 16,000 per study. In addition to the primary surveys, additional related studies were mined for pertinent information.

The primary conclusions of the surveys reviewed are that the public knows very little about hydrogen and fuel cell technologies but is generally accepting of the potential for hydrogen use. In general, respondents consider themselves as environmentally conscious. The public considers safety as the primary issue surrounding hydrogen as a fuel. Price, performance, and convenience are also considerations that will have major impacts on purchase decisions.
\end{abstract}




\section{ACRONYMS}

$\begin{array}{ll}\text { CATI } & \text { Computer Assisted Telephone Interview } \\ \text { CFCP } & \text { California Fuel Cell Partnership } \\ \text { DOE } & \text { Department of Energy } \\ \text { EERE } & \text { Energy Efficiency and Renewable Energy } \\ \text { HFCIT } & \text { Hydrogen, Fuel Cells, and Infrastructure Technologies } \\ \text { HTAP } & \text { Hydrogen Technical Advisory Panel } \\ \text { LBST } & \text { Ludwig-Bölkow-Systemtechnik } \\ \text { NREL } & \text { National Renewable Energy Laboratory } \\ \text { OMB } & \text { Office of Management and Budget } \\ \text { ORC } & \text { Opinion Research Corporation } \\ \text { ORNL } & \text { Oak Ridge National Laboratory } \\ \text { SAE } & \text { Society of Automotive Engineers }\end{array}$




\section{INTRODUCTION}

The U.S. Department of Energy (DOE) Hydrogen, Fuel Cells, and Infrastructure Technologies (HFCIT) program integrates hydrogen and fuel cells subprograms, coordinates research efforts, and communicates information through educational activities. The purpose of the Baseline Knowledge Assessment for the HFCIT program is to measure the current level of awareness and understanding of hydrogen and fuel cell technologies and the hydrogen economy. This information will be an asset to the HFCIT program in formulating an overall education plan. It will also provide a baseline for comparison of future evaluations of public awareness, knowledge, and opinion.

\subsection{BACKGROUND}

"Hydrogen, in vast quantities, has been used safely in chemical and metallurgical applications, the food industry, and the space program for many years. In the not-sodistant future, hydrogen and fuel cells will play an even greater role in meeting the energy needs of our nation and the world."1

The use of hydrogen as an energy carrier and fuel cells as power producers is not new. Applications include stationary systems, portable products, and transportation-related vehicles.

Stationary applications, which provide the oldest examples of the fuel cell industry, have been in development since the 1960s. Fuel Cell Today estimates that about 530 complete systems, each having electrical output over $10 \mathrm{~kW}$, have been operated worldwide. ${ }^{2}$ While, in the past, Japan has been the leader in stationary fuel cell development, the United States has also supported development. Most of these systems were fueled by natural gas. ${ }^{3}$

Portable applications of fuel cells have also been in use since the 1960s; Fuel Cell Today estimates that about 1,700 complete systems, with electrical power output between $1 \mathrm{~W}$ and $1.5 \mathrm{~kW}$, have been operated worldwide. The United States is the primary region in which portable fuel cell development is on-going, although the primary applications are for military, not commercial, uses. ${ }^{4}$

Fuel cells have also been used in transportation-related applications. Fuel cell applications in buses began in 1993; by late September 2002, about 31 fuel cell buses had been built and operated worldwide. ${ }^{5}$ Research and development on fuel-cell-powered light-duty vehicles escalated in the mid-1990s; Fuel Cell Today projects that there are

\footnotetext{
${ }^{1}$ U.S. Department of Energy, Hydrogen, Fuel Cells, and Infrastructure Technologies Program, "Safety, Codes \& Standards," http://www.eere.energy.gov/hydrogenandfuelcells/codes/ .

${ }^{2}$ Fuel Cell Today, "Fuel Cell Market Survey: Stationary Applications," p. 1.

${ }^{3}$ Fuel Cell Today, "Fuel Cell Market Survey: Stationary Applications," pp. 2-3.

${ }^{4}$ Fuel Cell Today, "Fuel Cell Market Survey: Portable Applications," pp. 1-3.

${ }^{5}$ Fuel Cell Today, "Fuel Cell Market Survey: Buses,” p. 1.
} 
will be over 300 light-duty vehicle models by the end of $2003 .{ }^{6}$ Approximately 340 transportation-related fuel cell systems, other than buses and light-duty vehicles, have been built. Of this number, about 200 have been for spacecraft applications. ${ }^{7}$

\subsection{PURPOSE OF THE LITERATURE REVIEW}

The terms "poll" and "survey" are used interchangeably in this report. There is, however, a distinction made between scientific polls (or surveys) and non-scientific polls (or surveys). A scientific survey is carefully constructed to provide statistically representative results within a known margin of error. A non-scientific survey lays no claim to accuracy; it might simply solicit responses from anyone who happens upon the poll, is interested in providing an opinion, and has a mechanism (e.g., a phone or internet access) for responding.

In order to assess the current understanding of hydrogen and fuel cells technologies and applications (information important to developing successful education strategies), the HFCIT program plans to conduct scientific surveys of four target audiences. Surveys of the general public, the educational community, governmental agencies, and potential large users will provide a baseline knowledge assessment for each of these groups.

DOE will conduct identical surveys in 2004, 2007, and 2010 in order to obtain an accurate understanding of whether knowledge and opinions about hydrogen technologies have changed over time. Because consistency of methodology and approach are critical, the survey instrument developed for use in 2004 will be used with the same target audiences and will be administered using precisely the same methodology in 2007 and 2010 .

The purpose of this literature review is to examine the literature and summarize the results of surveys that have been conducted in the recent past concerning the existing knowledge of hydrogen, hydrogen technologies, and the hydrogen economy. This literature review covers both scientific and, to a lesser extent, non-scientific polls. Such information can enlighten the HFCIT knowledge assessment activity and will be helpful in designing the HFCIT survey. The information gained in this literature review does not, however, replace the need for the HFCIT surveys. No single survey included in this literature review covered all of the audiences that will be included in the HFCIT knowledge assessment surveys. In addition, no other survey had plans to repeat the identical survey at a future point to assess changes in knowledge and opinions.

\subsection{OVERVIEW}

This literature review is divided into two sections, one of which contains reviews of surveys that are considered of primary relevance. The other section contains reviews of

\footnotetext{
${ }^{6}$ Fuel Cell Today, "Fuel Cell Market Survey: Light-Duty Vehicles,” p. 1.

${ }^{7}$ Fuel Cell Today, "Fuel Cell Market Survey: Niche Transport Applications,” p. 1.
} 
other surveys, which are less relevant to the proposed HFCIT knowledge assessment activity. Several factors are involved in the categorization, including whether the poll is directly related to hydrogen and fuel cell technologies and whether the poll is scientific or non-scientific.

It should be noted that many technical studies have been conducted on hydrogen and fuel cell technologies, infrastructure development, safety, and other related issues. Reports documenting these studies and other experimental results are available. It is unknown, however, how much impact, if any, these technical reports have on the general public.

Few surveys to determine the existing knowledge base have been conducted and published. The primary surveys are itemized in the list below in chronological order and are described in more detail in Section 2. A shortened title, which will be used in this report, is highlighted in brackets at the end of the citation. Complete references to these surveys are provided in the listing of Primary Sources in the References at the end of this paper.

- Hydrogen Technology Advisory Panel (HTAP), Survey Report May 4, 1998, available from http://www.eere.energy.gov/hydrogenandfuelcells/advisory_panels.html , 1998 [HTAP survey].

- European Commission,The Acceptance of Hydrogen Technologies, study carried out by Matthias Altmann, Ludwig-Bölkow-Systemtechnik GmbH (LBST), Ottobrunn, Germany, and Cornelia Gräsel, Ludwig-Maximilians-Universität München Institute for Educational Psychology, München, Germany, www.hyweb.de/accepth2, September 1998 [European Commission Accept H2 surveys].

- Breakthrough Technologies Institute, Survey Results - Fuel Cell Education Survey, conducted by Bill Frederick Communications, Palm Harbor, Florida, accessible via the FuelCell2000 library at http://www.fuelcells.org/biblio.htm , 2002 [Breakthrough Technologies survey].

- Rocky Mountain Poll, "Reducing U.S. Dependency on Foreign Oil: 35 MPG Requirements and Emerging Hydrogen Fuel Technology Seen as Important Strategies,” Behavior Research Center, Inc., Phoenix, Arizona, Report 2002-IV-14, http://www.brcpolls.com/pra02.htm , November 2002 [Rocky Mountain Poll].

- European Commission, EUROBAROMETER - Energy: Issues, Options and Technologies, Science and Society, The European Opinion Research Group, http://europa.eu.int/comm/public_opinion/archives/eb/ebs_169.pdf , December 2002 [European Commission Eurobarometer survey].

- Gurikova, Tatyana, Transportation Energy Survey Data Book 1.1, ORNL/SUB/024000008627/01, Oak Ridge National Laboratory, Oak Ridge, Tennessee, May 2002; also Steiner, Elyse, Consumer Views on Transportation and Energy, DRAFT, National Renewable Energy Laboratory, June 2003 [transportation energy surveys].

- Millennium Cell and U.S. Borax Inc., "Harris Poll Shows Americans' Early Preferences and Requirements for Hydrogen Fuel-Powered Vehicles: Safety, Cost, and Vehicle Range Are Key Consumer Needs," http://www.millenniumcell.com/cgi- 
bin/news.pl?function=detail\&id=06112003 , June 11, 2003 [Millennium Cell survey].

Section 2 of this report will concentrate on these primary surveys that directly refer to opinions about and baseline knowledge and acceptance of hydrogen, fuel cells, and the infrastructure needed to support a hydrogen economy. Section 3 will provide brief accounts of additional related studies of particular interest. 


\section{REVIEW OF PRIMARY SOURCES}

The surveys reviewed in this section are of particular relevance. These studies are reviewed below in, more or less, chronological order by publication date.

\section{$2.1 \quad$ HTAP SURVEY, $1998^{8}$}

The Hydrogen Technical Advisory Panel (HTAP) conducted a survey of individuals in research, industry, and government who were involved in or interested in hydrogen. Of 77 persons on the original contact list, 52 questionnaires were returned - 49 completed and three blank. Survey respondents were categorized as follows:

- Industry, $36 \%$

- Government, $23 \%$

- Non-profit, $14 \%$

- University, $9 \%$

- Other (including national laboratory respondents), $18 \%$

The survey was a prepared questionnaire and contained both closed-end ratings (e.g., good, acceptable, poor) and open-end requests for comments. Both telephone interviews and mailed-in responses were used. Telephone interviews, conducted by HTAP members, were expected to take 30-45 minutes to complete.

The questionnaire consisted of ten sections: personal data, project execution (limited to respondents who were involved in hydrogen projects), DOE program management, the balance of elements within the hydrogen program, commercialization of hydrogen energy systems, coordination and partnering, outreach and communication, hydrogen budgets and legislation, major hydrogen energy issues, and additional comments.

Because the survey is over five years old and many changes have occurred in the DOE hydrogen program since the report was published, not all of the results of this survey are still applicable. Two question areas that are pertinent to an assessment of baseline knowledge are (1) outreach and communication and (2) major hydrogen energy issues. Each of these question areas and their results are summarized below. The remarks and comments based on open-end questions are not tallied, because they are too general to statistically quantify.

\subsubsection{Outreach and Communication}

The following question was asked: "The hydrogen program strives to raise the visibility of hydrogen energy through its outreach and communication, which consists of several components; for example: 1) Support for hydrogen codes and standards development, 2) Development of educational materials, 3) Technical, promotional, and planning publications, 4) the World Wide Web, 5) HTAP public meetings and 6) participation of

\footnotetext{
${ }^{8}$ Hydrogen Technology Advisory Panel, Survey Report, May 4, 1998.
} 
outside experts from industry and academia in annual peer reviews of core R\&D projects. Please rate the quality of the hydrogen program's outreach and communications efforts.” The rating scale was good, acceptable (or medium), and poor. A score was assigned based on good $=5$, acceptable $=3$, and poor $=1$. The statistical results are given in Table 1. For each question, the percent of responses within each rating scale is given, as well as the total average score.

\begin{tabular}{|l|c|c|c|c|}
\hline \multicolumn{1}{|c|}{ Table 1. Ratings for HTAP survey question on outreach and communication efforts } \\
\hline \multirow{2}{*}{ Question } & \multicolumn{2}{c|}{ Rating (\% of responses) } & \multirow{2}{*}{ Score } \\
\cline { 2 - 5 } & $\begin{array}{c}\text { Good } \\
\mathbf{( 5 )}\end{array}$ & $\begin{array}{c}\text { Acceptable } \\
\text { (3) }\end{array}$ & $\begin{array}{c}\text { Poor } \\
\text { (1) }\end{array}$ & \\
\hline In safety, codes and standards & 68 & 29 & 3 & 4.30 \\
\hline In public outreach & 32 & 29 & 38 & 2.85 \\
\hline With industry & 33 & 52 & 15 & 3.36 \\
\hline At high government levels (DOE, Congress) & 13 & 45 & 41 & 2.46 \\
\hline Average score & & & & 3.24 \\
\hline
\end{tabular}

The outreach and communication efforts for the safety, codes and standards area received higher scores than the other areas. Communication with high government levels received the lowest scores of any category, with only $13 \%$ of the respondents thinking that the communication was "good.” Additional comments pointed to inadequate promotion of the program as well as a lack of vision.

\subsubsection{Major Hydrogen Energy Issues}

The following question was asked: "Numerous needs and barriers confront the successful implementation of hydrogen energy systems. Several are listed below. Please rank the importance of each in terms of High, Medium, and Low.” The statistical results of this question are given in Table 2. For each question, the percent of responses within each rating scale is given, as well as the total average score.

\begin{tabular}{|l|c|c|c|c|}
\hline \multirow{2}{*}{\multicolumn{1}{|c|}{ Quable 2. Ratings for HTAP survey question on major hydrogen energy issues }} \\
\hline & \multicolumn{2}{c|}{ Rating (\% of responses) } & \multirow{2}{*}{ Score } \\
\cline { 2 - 5 } & $\begin{array}{c}\text { High } \\
\mathbf{( 5 )}\end{array}$ & $\begin{array}{c}\text { Medium } \\
\mathbf{( 3 )}\end{array}$ & $\begin{array}{c}\text { Low } \\
\mathbf{( 1 )}\end{array}$ & \\
\hline Production cost - fossil & 28 & 35 & 37 & 2.82 \\
\hline Production cost - renewables & 74 & 21 & 5 & 4.38 \\
\hline Storage & 70 & 23 & 7 & 4.26 \\
\hline Market readiness - vehicles & 44 & 37 & 19 & 3.50 \\
\hline Market readiness - stationary & 28 & 56 & 16 & 3.24 \\
\hline Industry participation & 38 & 40 & 21 & 3.31 \\
\hline Infrastructure & 53 & 26 & 21 & 3.64 \\
\hline Codes \& standards, insurance & 38 & 40 & 21 & 3.31 \\
\hline Competing technologies, fuels & 63 & 33 & 5 & 4.19 \\
\hline Federal RD\&D budgets & 47 & 35 & 19 & 3.59 \\
\hline Low visibility & 40 & 37 & 23 & 3.34 \\
\hline Public perception & 44 & 30 & 26 & 3.36 \\
\hline
\end{tabular}


The top three issues facing the hydrogen program, according to respondents of this survey, were the production cost of renewable energy, storage issues, and issues surrounding competing technologies and fuels. The least important barrier, according to these respondents was production cost using fossil fuels, the only item in the list scoring less than " 3 " (medium) in importance.

\subsection{EUROPEAN COMMISSION ACCEPT H2 SURVEYS, $1998^{9}$}

This three-part study was managed by Altmann and Gräsel for the European Commission during 1997 and 1998. Results were published in September 1998. The surveys were conducted in Germany to determine the level of acceptance of hydrogen technologies, to ascertain the level of knowledge about hydrogen technologies, and to establish whether there was a demand for additional information about hydrogen technologies. Two population groups were surveyed - secondary school students and passengers on a hydrogen-powered bus. A subgroup of students who rode the hydrogen-powered bus was analyzed separately. Because this is the only survey that specifically targeted students, it is reported in detail.

\subsubsection{Student Survey}

A total of 410 students at three schools in Germany participated. The questionnaire, which was filled out in classrooms at the schools, required about 30 minutes to complete.

In the first part of the survey, students were asked to name everything they could think of related to the term "hydrogen." Although there was no score for this free association task, the responses were classified into categories; one purpose of this exercise was to ascertain whether the students would associate hydrogen with positive or negative terms. The results of the classification are as follow: chemical knowledge directly related to hydrogen (59\%), chemical knowledge indirectly related to hydrogen (7\%), hydrogen technologies (11\%), the Hindenburg (0.3\%), hydrogen bomb (9\%), threat/danger (3\%), positive assessment or environmental friendliness (3.4\%), and other (8\%).

To assess the students' acceptance of hydrogen technologies, eight statements were rated by the students on a 5-point scale, from "disagree completely" to "agree completely." The average scores on each of the eight statements were very positive - all but two were over 4 . The results of one of the two negative statements indicated that students would generally not be willing to pay more for hydrogen (for fuel) than for gasoline. The other indicated that students felt that hydrogen is dangerous because of potential explosions. The overall average score was 4.04 (out of 5), with a standard deviation of 0.56 . In addition to the eight statements, students were also asked an open-ended question about impediments to a hydrogen economy. Their responses were then classified into various categories. The top five categories were as follows: costs (34\%), danger (14\%), lobbyism

\footnotetext{
${ }^{9}$ European Commission, The Acceptance of Hydrogen Technologies, September 1998.
} 
- e.g., the oil industry (11\%), effort of production/transport (11\%), and public acceptance $(10 \%)$.

To assess the students' knowledge of hydrogen as a fuel, one open-ended question was asked ("Which exhaust gases result from the use of hydrogen as a fuel?") along with two true-false statements, resulting in a possibility of four "points.” Although the students were very accepting of hydrogen technologies, their knowledge level was very low. No student received all four points and only 13 students received three points. Of the 410 students completing the survey, 114 received 2 points, 159 received 1 point, and 67 were unable provide any correct responses.

In addition, students were asked questions about their environmental knowledge and practices (consumption/rubbish and mobility). Both multiple choice and open-ended questions were used. The students' environmental awareness and attitudes were compared with their acceptance of hydrogen technologies. It was found that environmental attitudes and behavior have slightly positive (but statistically significant) correlations with acceptance of hydrogen technologies ( $\mathrm{p}<0.01$ in both cases).

Students indicated that their primary sources of information about hydrogen are mass media (51\%) and school (32\%). They also indicated that school would be their preferred avenue for receiving information.

\subsubsection{Survey of Bus Passengers}

The bus survey was conducted of passengers boarding a hydrogen-powered bus. The survey of bus passengers was similar to, but shorter than, the survey of students (e.g., no knowledge questions were asked). Every tenth person boarding the bus was interviewed; of a total of 145 persons, 80 were women and 65 were men. The average age was 40 years.

In the free association task, passenger responses were categorized as follows: chemical knowledge directly related to hydrogen (23\%), chemical knowledge indirectly related to hydrogen (9\%), hydrogen technologies (6\%), the Hindenburg $(0.1 \%)$, hydrogen bomb (13\%), threat/danger (5\%), positive assessment or environmental friendliness (40\%), and other (3\%).

A high level of acceptance for the hydrogen bus was indicated (a score of 4.28 out of a possible 5). The danger of explosion, however, was noted as a slight concern.

There was a slight positive correlation between environmental awareness and acceptance of hydrogen technologies.

When asked about whether they had already received any information about hydrogen technologies, over $37 \%$ of the persons on the bus replied that they had. When these persons were then asked about their source of information, responses were mass media (55\%), school (20\%), professional content (9\%), and bus operator (15\%). When asked if 
they were interested in receiving further information, over half of the passengers replied that they were.

\subsubsection{Summary}

In summary, both the students and the bus passengers had a high level of acceptance for hydrogen technologies; however, the level of knowledge among the students about these same technologies was extremely low. Because people tend to reject new technologies about which they know little, this survey result is surprising. The study authors surmised that media reporting about hydrogen has been primarily about the environmental advantages and less about potential risks. In addition, the bus passengers had experienced no problems.

For the students, acceptance tended to be slightly higher among boys, older students, and students who were more environmentally conscious. Students interviewed in the bus provided more accepting positive statements about hydrogen than students in the classroom, which indicates that people who are in direct contact with hydrogen technologies that are working well will be more accepting.

Students preferred to receive instruction from schools but also mentioned the internet as a source of scientific information. Both students and bus passengers expressed a desire for more information.

Only a slight positive correlation was found between acceptance of hydrogen technology and either technical knowledge about hydrogen or degree of concern about the environment.

\subsubsection{Further Research}

An additional hydrogen acceptance project is being conducted (Fall 2003) in five different countries to compare "before" and "after" public attitudes. ${ }^{10}$ The work is being conducted in London, Luxembourg, Munich, Perth, and Oakland, California. The purpose of the project is to analyze and compare public knowledge and perceptions of fuel cells and hydrogen before and after the introduction of hydrogen buses in the cities.

Results of this research have not been published. A 30-foot prototype fuel cell bus will continue in revenue service in three cities in California through November 2003. Three $40-\mathrm{ft}$ buses are under construction. Anecdotal information, which is being collected on the prototype bus, has been positive and enthusiastic. ${ }^{11}$

\footnotetext{
${ }^{10}$ Altmann, Matthias, Ludwig-Bölkow-Systemtechnik GmbH, personal communication with Tykey Truett, ORNL, August 15, 2003.

${ }^{11}$ Levin, Jamie, AC Transit, personal communication with Tykey Truett, ORNL, October 16, 2003.
} 


\subsection{BREAKTHROUGH TECHNOLOGIES SURVEY, $2002^{12}$}

This survey was conducted in the Spring and early Summer of 2002 by Bill Frederick Communications of Palm Harbor, Florida, for Breakthrough Technologies Institute in Washington, D.C. The purpose of the survey was to identify the most appropriate target audiences for a hydrogen/fuel cell education program and to determine the focus of such a program.

The survey contained 13 questions. All interview questions except one were open-ended; the statistical analysis was limited. The survey was conducted on a small universe of fuel cell experts, divided into two groups.

The first group consisted of 20 leaders from academia, the private sector, and government, who were interviewed via telephone calls; there were 19 completed interviews. Each interview was expected to last 20-30 minutes. The second group, which was a more hands-on and diverse population, consisted of 120 individuals involved in different aspects of fuel cell development, who received e-mailed questionnaires; unfortunately, only 17 questionnaires were returned, of which 13 contained useful responses.

The first question provided a list of likely audiences for an education program; respondents were asked to rate the audiences from 1 (low) to 5 (high) according to their importance. There were some differences in the responses depending on the two groups interviewed. Both groups agreed that the most important audiences needing education were legislators and policy makers. ${ }^{13}$

The remaining questions of this survey were open-ended. Responses from the 32 completed surveys were compiled, sorted, and analyzed. Some of the more pertinent conclusions of this survey are as follows:

- Education of law- and rule-makers is very important. The least important audiences are the investment community and business executives.

- The education program should contain basic, simple messages. Sophisticated programs or complicated messages would be less useful.

- The primary emphases of these messages should include environmental benefits, energy independence, and an emphasis on fuel cells as the technology for the future.

- Safety concerns must be addressed.

- Benefits of fuel cells need to be emphasized.

\footnotetext{
${ }^{12}$ Breakthrough Technologies Institute, Survey Results - Fuel Cell Education Survey, 2002.

${ }^{13}$ The audiences receiving the highest average scores based on telephone interviews were legislators, code bodies, policy makers, news media/opinion leaders, and State/local regulators (averages between 4.1 and 4.53). The most important audiences based on the e-mailed responses were legislators, policy makers, and financial incentive providers (averages between 4.0 and 4.58). The audience considered least important by the telephone respondents was consumer organizations (average score of 3.05); the audience considered least important by the e-mail respondents was the investment community (average score of 2.83).
} 
- Education of the public is not as important as education of stakeholders. It was noted that many stakeholder groups know very little about fuel cells.

- Technical information is needed by policy makers, legislators, investment communities, and other groups; in-depth technical knowledge is needed by universities and industry.

- Applications education is needed, but respondents were unable to articulate the exact needs.

\subsection{ROCKY MOUNTAIN POLL, $2002^{14}$}

From November $7^{\text {th }}$ through November $12^{\text {th }}, 2002$, 603 telephone interviews with adult heads of household were conducted in Maricopa County, Arizona. The poll was conducted by the Behavior Research Center of Arizona, an independent and non-partisan research group. According to these pollsters, the results have a statistical precision of $\pm 4.1 \%$ with a $95 \%$ certainty.

Three questions were asked:

1. "Looking to the future, how important do you think it is for the United States to reduce its dependence on foreign oil?”

2. "In reducing U.S. dependence on foreign oil, do you think it is very important, somewhat important or not important to do the following...?” Five actions were then listed for evaluation.

3. "In the coming years major manufacturers, such as General Motors, expect to begin selling new hydrogen-fueled passenger vehicles that use no gasoline and produce no pollution. Assuming competitive pricing and the availability of convenient fueling stations, if such cars were available today, would you definitely, probably, probably not, or definitely not consider buying a hydrogenfueled vehicle?”

A total of $67 \%$ of the respondents to the first question considered it very important to reduce dependence on foreign oil, and another $25 \%$ thought it somewhat important.

Of the five actions listed in Question 2, the first action to be ranked was "Develop automobiles that use alternative fuels such as clean burning hydrogen.” An overwhelming $71 \%$ of the respondents listed this action as very important; another $20 \%$ listed it as somewhat important, and only 9\% responded that it was not important or that they were unsure of its importance. Figure 1 shows the responses to all five of the actions listed in Question 2 as possible ways to decrease dependence on foreign oil.

${ }^{14}$ Rocky Mountain Poll, “Reducing U.S. Dependency on Foreign Oil ...,” November 2002. 


\section{Importance of specific actions to reduce U.S. dependence on foreign oil}

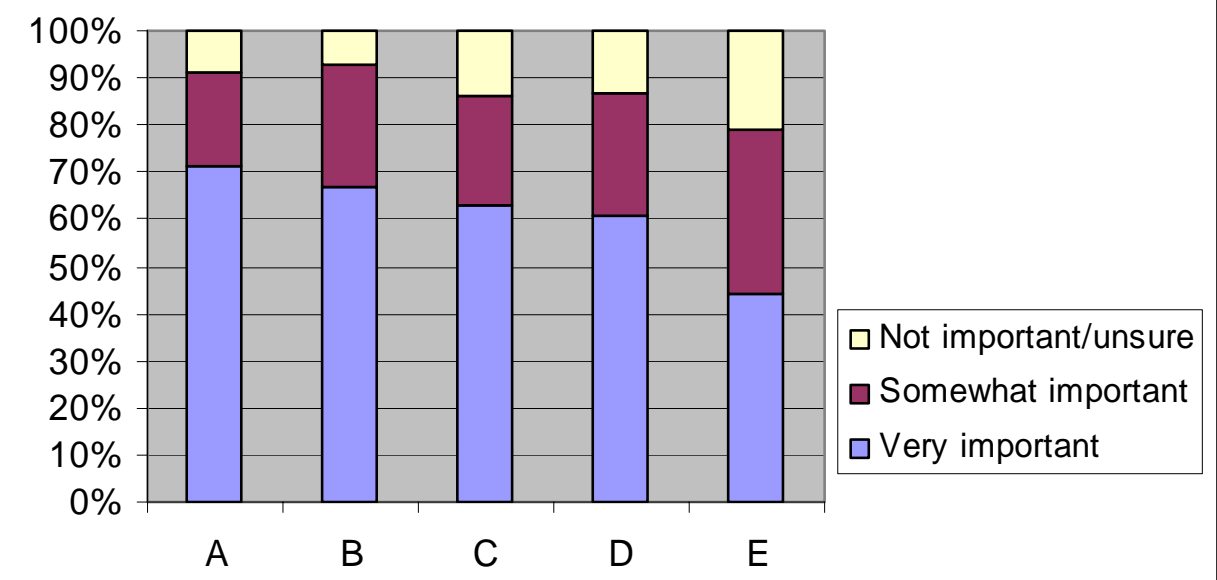

$A=$ Develop automobiles that use alternative fuels such as clean burning hydrogen

$B=$ Encourage industry to shift to alternative energy sources for their manufacturing and other operations

$\mathrm{C}=$ Require that gasoline-powered passenger cars ... get at least $35 \mathrm{mpg}$

$\mathrm{D}=$ Require gas stations ... to provide alternative fuels to customers

$\mathrm{E}=$ Require electric generating companies to phase out generating plants that are powered by oil

Figure 1. Responses to Rocky Mountain Poll question on how to reduce U.S. dependence on foreign oil.

In Question 3, 78\% of the respondents indicated that they would purchase this automobile, which they considered very important to develop, if it were comparable in price and refueling convenience. Only 31\%, however, would definitely purchase such a vehicle. The percentages of responses are provided in Table 3.

\begin{tabular}{|c|c|}
\hline Response & Percentage of responses \\
\hline Definitely & 31 \\
\hline Probably & 47 \\
\hline Probably not & 13 \\
\hline Definitely not & 6 \\
\hline Unsure & 3 \\
\hline
\end{tabular}




\subsection{EUROPEAN COMMISSION EUROBAROMETER SURVEY, $2002^{15}$}

This survey analyzed attitudes of the general public (ages 15 and over) within the 15 member states of the European Union regarding energy and energy technology issues. It was conducted between February and April 2002. A total of 16,032 persons were interviewed using a multi-stage, random sample for each country based on population size and density. The questions were read in the official language of each country. Results provided in the report are weighted for the European Union as a whole and for each member state individually.

The overall goal of this survey was to obtain a clearer picture of public opinion about and understanding on energy-related issues, including the public perception of the future. A summary of the overall results of the survey by general topic area showed that opinions differ throughout the European Union based on region (especially noted were differences between northern and southern European countries) and on level of education and social background.

\subsubsection{General Perceptions}

Nearly $90 \%$ of the respondents felt that global warming was a serious problem, and respondents indicated that they wanted to see immediate action taken. Almost 75\% considered transportation to be largely responsible for climate change.

\subsubsection{Information}

Europeans indicated that they would like to receive guidelines on concrete energysavings features and on alternative forms of energy. They indicated that their primary sources of information on energy-related issues are television (80\%), newspapers (47\%), and radio (27\%). Internet-based sources of information were only identified by $10 \%$ of the respondents. One question asked respondents to indicate which of several topics they would like more information about (multiple responses were permitted). While $53 \%$ of the respondents indicated they would like to receive additional information about saving energy at home, only $39 \%$ indicated they would like more information about alternative vehicle fuels, and only $27 \%$ wanted to learn about new energy options such as fuel cells, hydrogen, etc.

\subsubsection{Perceptions of the Future}

Dependence on imported fuels is recognized as a problem, and Europeans identified both research into new energy sources and energy-saving policies as potential solutions. Interviewees were offered three choices for the top priority for energy policy; in decreasing order, respondents chose (1) protection of the environment, (2) low prices for consumers, and (3) uninterrupted energy supplies. In general, renewable energy sources

\footnotetext{
${ }^{15}$ European Commission, EUROBAROMETER - Energy: Issues, Options and Technologies, Science and Society, December 2002.
} 
were perceived as being the least expensive solution to the energy crises, as well as the best for the environment and most efficient.

\subsubsection{Behavior of the Public}

Most of the actions Europeans take to conserve energy are within the home. Most of the public believed that changes to industry could have the greatest impact on energy savings and that greater regulations are needed for industry. Responses indicated that those interviewed would accept stricter regulation for the general public for cars and insulation of buildings.

As noted above, the findings of this survey differed by region and socio-demographic background. Slight differences for gender were noted, in that women tended more often to fall into the “don't know” category. Differences by age and political leanings were less identifiable.

\subsection{TRANSPORTATION ENERGY SURVEYS, 2002 AND 2003}

A series of reports have been issued by the U.S. DOE to inform DOE project managers in the Office of Energy Efficiency and Renewable Energy (EERE) of market characteristics and public opinions on energy and environmental issues. The reports, which began in 1997, help to ensure that EERE technologies will be sufficient in meeting the nation's energy needs. Two reports of the series are discussed below.

\subsubsection{Transportation Energy Survey Data Book $1.1^{16}$}

This report provides results of transportation surveys regarding (1) energy and the environment and (2) alternative fuels and advanced technologies. Data were drawn from surveys conducted from 1998 through 2001 by Opinion Research Corporation (ORC) International for the National Renewable Energy Laboratory (NREL) and other polls and newspaper articles. The results in this section were drawn from the ORC polls.

ORC conducts surveys using a computer assisted telephone interview (CATI). A statistically designed random sample is used to select households; calls involve about 1,000 adults (18 and older). Up to four attempts are made to complete the calls. ${ }^{17}$

In 1998, 1,000 persons were asked the question "In what year in the future do you think gasoline and diesel will become too expensive in cars and trucks?” Although $34 \%$ of the respondents indicated that they did not know, 40\% considered 2010 as an upper bound. When asked which fuel would most likely replace gasoline and diesel in the future (openended question), most responses (33\%) favored electricity/battery, 25\% of the respondents indicated that they did not know, and only 3\% selected hydrogen.

${ }^{16}$ Gurikova, Tatyana, Transportation Energy Survey Data Book 1.1, May 2002.

${ }^{17}$ ORC International, “Detailed Tabulations of Caravan ...,” February 2002. 
In the year 2000, a similar survey was conducted (though the questions posed were not identical). When given a choice of electricity, ethanol, or hydrogen as the best fuel to replace gasoline, responses revealed that 52\% now considered electricity as the best fuel for personal vehicles when gasoline is not available, and 151 persons (15\%) responded hydrogen. Those persons who chose hydrogen as the best fuel were asked an open-ended question about the reasons that they considered hydrogen the best alternative to gasoline. The most common response was the abundance of hydrogen, followed closely by environmental advantages. The same survey asked respondents which fuel (ethanol, hydrogen, or electricity) would be the worst fuel to replace gasoline. Those 274 persons (27\%) who chose hydrogen as the worst fuel were asked an open-ended question about the reasons that they considered hydrogen the worst alternative to gasoline. The most frequent reason (over 50\%) was safety concerns (explosive, flammable, etc.).

Also in 2000, a question was asked about the purchase of a new vehicle and the possible choice of a new engine which uses a new fuel. The respondent was given information that the new engine and fuel would cost the same as a conventional engine and gasoline and, in addition, the new fuel would get $50 \%$ more miles per gallon. The respondent was asked which vehicle would he/she be most likely to buy for each of the following scenarios:

- Fuel is only sold at 1 in 10 stations,

- Fuel is only sold at 1 in 5 stations,

- Fuel is only sold at 1 in 3 stations.

While only $30 \%$ of the respondents indicated that they would buy the new more fuelefficient engine if its availability was limited to 1 in 10 stations, 59\% indicated that they would buy if fuel was available in 1 of 3 stations.

\subsubsection{Consumer Views on Transportation and Energy ${ }^{18}$}

In 2003, another report was published which updated the survey data discussed in Section 2.6.1. This report used data from various polls, newspaper articles, and statistical surveys conducted by ORC International.

Similar to the report discussed in Section 2.6.1, this report is more an analysis of what people think of energy, energy policies, and alternative fuels than an analysis of what people think specifically about hydrogen. The report repeats some of the same data reported in the Gurikova report (see footnote 14). The report noted that $86 \%$ of the respondents were in favor of decreasing our nation's dependence on foreign oil (Steiner, Table 2.1.2); however, people were not always willing to pay more for higher efficiency. Indeed, only $20 \%$ of the respondents were willing to pay more than an additional \$2,500 for a vehicle with increased fuel efficiency (Steiner, Table 5.2.5).

Another important finding noted in this report is that the public lacks understanding about hybrid vehicles and about hydrogen and alternative fuels. For example, when respondents

${ }^{18}$ Steiner, Elyse, Consumer Views on Transportation and Energy, June 2003. 
were asked how much they had heard about advanced hybrid-electric powertrains, only about half responded that they had heard "some" information (Steiner, Table 5.3.1).

Knowledge about alternative-fueled vehicles seems to be increasing. When asked to name one of the hybrid-electric cars, the percent of respondents who could name a vehicle increased as follows (Steiner, Table 5.3.2.1):

- $\quad$ in $2000,36 \%$;

- in 2001, 44\%;

- in 2002, 51\%.

\subsection{MILLENNIUM CELL SURVEY, $2003^{19}$}

A poll commissioned by Millennium Cell and U.S. Borax Inc. and conducted by HarrisInteractive in April 2003 included 1,006 American adults, age 18 or older. The margin of error for the total sample was $\pm 3 \%$.

Table 4 shows several issues related to hydrogen-fueled vehicles and the percentages of respondents that rated the issues as being either "extremely" or "very” important.

\begin{tabular}{|l|c|}
\hline \multicolumn{1}{|c|}{$\begin{array}{c}\text { Table 4. Response to Millennium Cell survey question on factors } \\
\text { influencing decisions to try a new fuel technology }\end{array}$} \\
\hline \multicolumn{1}{|c|}{ Issue } & $\begin{array}{c}\text { Percentage of responses ranked as } \\
\text { "extremely" or "very" important }\end{array}$ \\
\hline How safe the fuel is for drivers and passengers & 83 \\
\hline The cost of the fuel & 78 \\
\hline How far you can drive before refueling & 75 \\
\hline The cost of the vehicle & 72 \\
\hline The convenience of refueling & 67 \\
\hline Environmental emissions & 67 \\
\hline $\begin{array}{l}\text { Whether the fuel source is domestic instead of } \\
\text { foreign }\end{array}$ & 47 \\
\hline $\begin{array}{l}\text { How the new fuel system affects passenger and } \\
\text { cargo space }\end{array}$ & 47 \\
\hline Whether or not the fuel can be recycled & 45 \\
\hline
\end{tabular}

As shown in Figure 2, respondents to the poll indicated that they would be willing to try a new hydrogen-based vehicle technology (85\%). Although willing to try a hydrogenfueled vehicle, when the question was rephrased in terms of cost, less than half (44\%) indicated that they would be willing to pay more for the technology. Indeed, 53\% said they were not willing to pay more. ${ }^{20}$

\footnotetext{
${ }^{19}$ Millennium Cell and U.S. Borax Inc., “Harris Poll Shows Americans’ Early Preferences and Requirements for Hydrogen Fuel-Powered Vehicles: Safety, Cost, and Vehicle Range Are Key Consumer Needs,” June 11, 2003.

${ }^{20}$ Tang, Stephen S., Millennium Cell Inc., “Consumer Demand as a Driver for New Technology,” presentation at the Hydrogen and Fuel Cells 2003 Conference and Trade Show, June 11, 2003.
} 


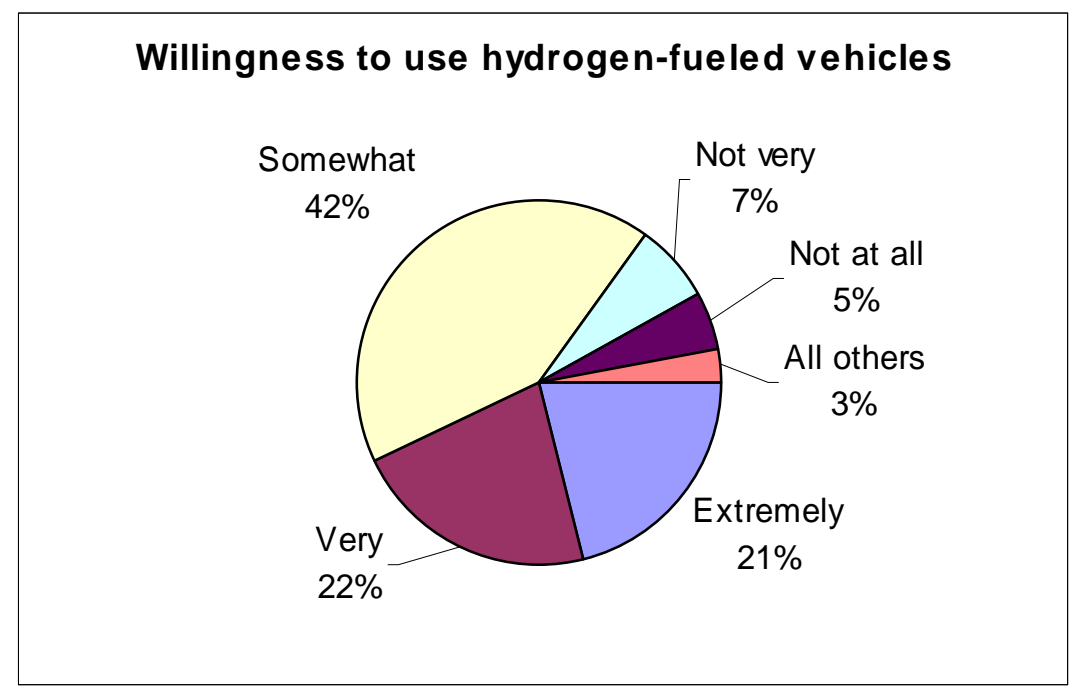

Figure 2. Willingness of Americans to try a new hydrogen-based technology to fuel vehicles. Source: Tang, Stephen S., Millennium Cell Inc., "Consumer Demand as a Driver for New Technology," presentation at the Hydrogen and Fuel Cells 2003 Conference and Trade Show, June 11, 2003.

According to this poll, Americans (in their own opinions) have very little understanding of hydrogen technologies. When respondents were asked to use a scale of "a great deal," "a moderate amount," "a little," and "nothing at all" to indicate their understanding of fuel technologies, most responses were "nothing at all” (compressed hydrogen, 57\%; liquefied hydrogen, $60 \%$; metal hydrides, $73 \%$; gasoline reformers, $74 \%$; and borax based liquid fuel, $77 \%$ ). 


\section{RELATED STUDIES}

The studies reviewed in this section are also useful in assessing attitudes; complete citations are provided in the listing of Other Sources in the References at the end of this paper. Although the polls described in Sections 3.1 and 3.2 contain questions specifically addressing fuel cells or hydrogen, they are non-scientific surveys.

The studies described in Section 3.3 concern on-site electricity generation (a potential use of fuel cells). Section 3.4 discusses a literature review of various studies, mostly in Europe, on the acceptance of hydrogen technologies. Sections 3.5-3.6 emphasize the frequency of polls on energy- and advanced-technology-related topics.

\subsection{CALIFORNIA FUEL CELL PARTNERSHIP}

The California Fuel Cell Partnership (CFCP) website contains a brief survey to solicit input from web viewers concerning fuel cell vehicles. ${ }^{21}$ There are three content questions and a question to obtain the respondent's age range. Questions allow the respondent (1) to check boxes to indicate the reasons he/she is interested in fuel cell cars, (2) to check boxes to indicate areas in which he/she wants additional information, and (3) to answer true-false to questions about having previously heard about fuel cell vehicles and/or the CFCP and about personal characteristics (e.g., being environmentally aware or a pioneer of new technology).

One of the questions asked why the respondents were interested in information about fuel cell cars. (Individuals could check as many items as desired.) At the end of August 2003, the responses to this question were as follows:

- Environmental benefits 133

- Fuel economy 106

- New fuel options 120

- Quiet vehicles 76

- Good driving performance 10

Most of the persons responding to this survey were 36-55 years old (46\%); another $40 \%$ were $21-35$. Only $4 \%$ of the respondents were under 20 years old. The vast majority (98\%) indicated they had heard or read about fuel cell vehicles before the day they responded to the survey, $94 \%$ indicated that they considered themselves environmentally aware, and 78\% considered themselves a new technology "pioneer."

It should be noted that this survey was not random, since only persons who had internet access, had an interest in fuel cells, and were willing to take the survey, provided input.

${ }^{21}$ California Fuel Cell Partnership, “Survey,” http://www.cafcp.org/cgi-local/survey/survey.cgi . 


\subsection{H2CARSBIZ}

Since February 2003, H2CARSBIZ has requested web visitors to provide opinions on the question, "Is using hydrogen as an energy carrier mostly about: Independence, Innovation, Energy Efficiency, or Environment?”22 As of the end of August 2003, 503 persons had voted, with the overwhelming majority of the responses (343) being "Environment." The H2CARSBIZ web-based survey places no claim to being representative of the general public or of any particular group. It is a non-scientific poll.

\subsection{RKS DISTRIBUTED RESOURCES STUDIES ${ }^{23}$}

Since 1998, RKS Research \& Consulting has conducted four separate surveys of businesses and homeowners to assess, within each population, an interest in onsite electricity generation. The most recent survey was conducted in April-May 2002. For each population, a phone interview lasting about 25 minutes was completed with approximately 600 respondents.

\subsubsection{Household Surveys}

In the 2000 survey, for households of $\$ 50,000$ or more income, the interest level was at $31 \%$. The 2002 survey of single-family households showed that $35 \%$ of all U.S. homeowners expressed interest in generating their own electricity. For households with incomes of $\$ 50,000$ or more, the interest level was $38 \%$. These results indicate that there is a growing market for onsite electricity generation. It must be stressed that two principal goals of this survey were to determine customer characteristics that influence interest in onsite generation and to assess features that appeal to potential customers of onsite generation. The survey series provides consumer trends since $1998 .{ }^{24}$ Homeowners with the greatest interest in onsite generation were persons with wells and persons living in California. ${ }^{25}$

\subsubsection{Business Surveys}

The 2002 business survey was conducted with energy decision-makers in businesses with at least 20 employees. Nine energy-essential industry categories were included: agriculture, casinos and gaming, communications, data processing related to financial institutions, food processing, health (hospitals), higher education, high tech, and pharmaceuticals. The number of interviews in each category was similar (between 50 and 94). The principal goal of the survey was to determine the characteristics of industry segments most interested in onsite generation. Secondary objectives were to determine

\footnotetext{
${ }^{22}$ H2CARS.BIZ, “Polls: Hydrogen Values,” http://www.h2cars.biz/artman/publish/cat_index_20.shtml .

${ }^{23}$ RKS Research \& Consulting, "Press Releases,” http://www.rksresearch.com .

${ }^{24}$ RKS Research \& Consulting, "Press Releases - Personal Power: More U.S. Homeowners Show Interest in On-site Options for Generating their Own Electricity,” http://www.rksresearch.com/press093002.html .

${ }^{25}$ Reichman, David J., RKS Research \& Consulting, personal communication with Tykey Truett, ORNL, August 4, 2003.
} 
desirable features and perceived benefits and to ascertain conditions that would lead to onsite generation as a solution. Industry segments that are especially sensitive to power outages or delivery problems expressed the greatest interest in obtaining onsite generation capabilities in the next five years. Cross-segment findings indicate that firms that have experienced power delivery problems and companies that place a high value on self-sufficiency are the most likely businesses to purchase onsite generating capability. ${ }^{26}$

\subsection{ADDITIONAL STUDIES DOCUMENTED BY ACCEPT H2}

The Accept H2 project conducted a literature review of studies concerning the acceptance of hydrogen technologies by the general public and within specific target groups. ${ }^{27}$ One of the studies reviewed is the European Commission Accept H2 study reported in Section 2.2.

One study that was cited by Accept $\mathrm{H} 2$ concerned a demonstration project of hydrogen fuel cell bus in Chicago. No details were provided about the methodology; the only publication cited is a press release, ${ }^{28}$ which indicates that driver and passenger reactions to the bus were positive.

Another attitudinal survey was conducted in London regarding the willingness of taxi drivers to pay more for hydrogen-fueled taxis. ${ }^{29}$ The findings indicated that (1) taxi drivers were not concerned with a possible negative reaction of riders with respect to hydrogen safety and (2) primary decisions regarding the purchase of hydrogen-fueled taxis would be based on expectations of personal financial gains.

Most of the studies reviewed by the Accept $\mathrm{H} 2$ project were conducted in Germany. The primary results from this review are as follows:

- $\quad$ Price and performance are more important factors in determining acceptance of cleaner vehicles than is environmental concern.

- There is no consensus on the relationship of knowledge on acceptance.

- Acceptance levels are higher among "users” of new technology (e.g., riders on a hydrogen-fueled bus).

One final summary of public preferences for clean vehicles and fuels concluded that there are discrepancies among surveys based on the type of survey that is conducted. Attitude surveys tend to be based on an ideal and are more positive toward alternative-fueled vehicles; experimental and preference surveys show lower acceptance levels because they reflect actual purchasing intentions. ${ }^{30}$

\footnotetext{
${ }^{26}$ RKS Research \& Consulting, "Press Releases - New National Survey Shows Increasing Interest in Onsite Power Generation Among Select Segments of U.S. Business,” http://www.rksresearch.com/press073002.html .

${ }^{27}$ Altmann, Matthias, Patrick Schmidt, Susana Mourato, and Tanya O’Garra, Analysis and Comparisons of Existing Studies, August 2003.

${ }^{28}$ Ballard News Release, http://www.ballard.com/pdfs/Pr000323_0.pdf .

${ }^{29}$ Altmann, et al, Analysis and Comparisons of Existing Studies, Section 3.1.7.

${ }^{30}$ Altmann, et al, Analysis and Comparisons of Existing Studies, Section 3.2.
} 


\subsection{GALLUP ORGANIZATION}

There are surveys that ask questions indirectly related to a future hydrogen economy. The Gallup Organization, for example, concluded at the end of 2001 that $80 \%$ of Americans favor Federal requirements for more energy-efficient automobiles. ${ }^{31}$ This poll was scientifically designed and analyzed; however, the question did not directly refer to hydrogen-fueled automobiles.

\subsection{TRANSIT OPERATORS STUDY}

In 2002, a limited survey of mass transit companies in Florida was conducted to determine interest in fuel cell bus technologies. ${ }^{32}$ No statistics were provided on the number of respondents or the methodology for collecting the data. Transit companies were given a list of potential benefits from the use of fuel cell technologies. When asked to rank the importance of the potential benefits, fleet operators indicated that they were interested in the following benefits (in order of interest): decreasing maintenance costs, decreasing emissions, increasing fuel efficiency, and decreasing downtime. Transit companies were much less interested in decreased noise and vibration and elimination of engine oil.

\subsection{OTHER MEDIA}

Television and newspapers frequently request public input to questions concerning energy and the environment. ${ }^{33}$ In addition, many market surveys have been conducted to collect information on numbers, types, locations, sizes, outputs, and uses of existing fuel cells. $^{34}$ The sheer number of this type of survey suggests that interest in alternative forms of energy, fuel cells, and the hydrogen economy is increasing.

\footnotetext{
31 The Gallup Organization, "Poll Analyses, 11/27/2001, Americans Favor Alternative Energy Methods to Solve Shortages,” http://www.gallup.com/subscription/?m=f\&c_id=10910 .

${ }^{32}$ Simmons, Timothy, et al., "A Preliminary Assessment of the Possible Acceptance of Fuel Cell Bus Technology by Current Fleet Vehicle Operators,” SAE Technical Paper 2002-01-3057.

${ }^{33}$ PollingReport.com, "Environment,” http://www.pollingreport.com/enviro.htm .

${ }^{34}$ See, for example, the Fuel Cells 2000 Fuel Cell Library at http://www.fuelcells.org/biblio.htm .
} 


\section{SUMMARY AND CONCLUSIONS}

Each of the primary surveys described in Section 2 had a different audience and purpose. The HTAP poll was addressed to a narrowly defined set of respondents, persons knowledgeable of or interested in the hydrogen economy in the United States. With a small set of respondents to interview and a short list of questions, open-ended comments were encouraged. Similarly, the Breakthrough Technologies survey also had a small set of respondents and requested opinions. The Rocky Mountain poll was conducted within a single county in Arizona; the population surveyed was the general public, and there were only three questions. The European Commission Eurobarometer survey was conducted in Europe and encompassed broader energy concepts than simply hydrogen; it was welldesigned for detailed statistical analysis. The Millennium Cell poll was a nationally representative sample of adults and was specifically directed to hydrogen issues. The European Commission Accept H2 survey, conducted in Germany in 1997-1998, was the only poll that included school students. It also addressed the acceptance of hydrogen technologies by people who had "experience" with the technology (i.e., passengers on a hydrogen-powered bus). The transportation energy surveys polled public opinions on new fuels and technologies with respect to environmental and policy issues and also compared people's willingness to pay for new technologies. Because the transportation energy surveys were conducted on different occasions over several years, they may be used to identify trends in public knowledge and opinion.

Related polls suggest that there is a growing interest in the potential of alternative fuels and advanced technologies, that hydrogen is seen as an environmentally friendly fuel, and that the public believes that Congress should legislate more energy-efficient automobiles; however they also suggest that the general public is not necessarily willing to pay more for advanced fuel and vehicle technologies.

\subsection{SUMMARY}

Table 5 lists the primary surveys reviewed in this paper and shows the variations in the approaches to the surveys. Because the objectives of the surveys differed, the choice of populations interviewed and the survey designs varied greatly.

There are some differences to be noted between the surveys reviewed in this paper and the surveys proposed by HFCIT. The transportation energy surveys show general trends; however, the questions were modified slightly for each survey. The questions posed in the HFCIT surveys will not change over time.

While the surveys conducted on very small populations had a greater latitude for asking open-ended questions, those conducted on large populations primarily used closed-end questions. The closed-end questions allowed more thorough statistical analyses and cross-comparisons. 


\begin{tabular}{|c|c|c|c|c|c|}
\hline \multicolumn{6}{|c|}{ Table 5. Overview and comparison of primary sources } \\
\hline Survey $^{a}$ & Site & Population & Responses & Format & Objective \\
\hline HTAP survey, 1998 & U.S. & $\begin{array}{l}\text { Persons in research, } \\
\text { industry, government }\end{array}$ & 49 & $\begin{array}{l}\text { Both closed- and } \\
\text { open-end questions }\end{array}$ & $\begin{array}{l}\text { Evaluation of hydrogen program elements and } \\
\text { identification of program issues }\end{array}$ \\
\hline $\begin{array}{l}\text { European } \\
\text { Commission Accept } \\
\text { H2 survey, } 1998 \\
\end{array}$ & Germany & $\begin{array}{l}\text { 1. Students } \\
\text { 2. Passengers of hydrogen- } \\
\text { fueled bus }\end{array}$ & $\begin{array}{l}1.410 \\
\text { 2. } 145\end{array}$ & $\begin{array}{l}\text { Both closed- and } \\
\text { open-end questions }\end{array}$ & $\begin{array}{l}\text { Knowledge about and acceptance of hydrogen } \\
\text { as a fuel; environmental practices; comparison } \\
\text { of knowledge and perception of risk }\end{array}$ \\
\hline $\begin{array}{l}\text { Breakthrough } \\
\text { Technologies survey, } \\
2002\end{array}$ & U.S. & $\begin{array}{l}\text { 1. Fuel cell experts in } \\
\text { academia, government, and } \\
\text { private sector } \\
\text { 2. Hands-on practitioners }\end{array}$ & $\begin{array}{l}1.19 \\
2.13\end{array}$ & \begin{tabular}{|l|}
13 questions, \\
primarily open-end
\end{tabular} & $\begin{array}{l}\text { General awareness and understanding of fuel } \\
\text { cells; identification of the education message }\end{array}$ \\
\hline $\begin{array}{l}\text { Rocky Mountain Poll, } \\
2002\end{array}$ & U.S. & $\begin{array}{l}\text { Adults, Maricopa County, } \\
\text { Arizona }\end{array}$ & 603 & $\begin{array}{l}\text { questions, closed- } \\
\text { end }\end{array}$ & $\begin{array}{l}\text { Dependence on foreign oil, willingness to buy } \\
\text { hydrogen vehicle }\end{array}$ \\
\hline $\begin{array}{l}\text { European } \\
\text { Commission } \\
\text { Eurobarometer } \\
\text { survey, } 2002\end{array}$ & $\begin{array}{l}\text { European } \\
\text { Union }\end{array}$ & $\begin{array}{l}\text { Adults (15+), member states } \\
\text { of the European Union }\end{array}$ & 16,032 & $\begin{array}{l}\text { Interviews; primarily } \\
\text { open-end }\end{array}$ & $\begin{array}{l}\text { Public opinion on energy-related issues, } \\
\text { including technologies }\end{array}$ \\
\hline $\begin{array}{l}\text { Transportation energy } \\
\text { surveys, 2002, } 2003 \\
\text { [Gurikova; Steiner] }\end{array}$ & U.S. & Adults (18+) & $\begin{array}{l}\text { About } \\
1,000\end{array}$ & $\begin{array}{l}\text { Both closed- and } \\
\text { open-end questions }\end{array}$ & $\begin{array}{l}\text { Dependence on foreign oil, knowledge of } \\
\text { energy situation, alternative fuels, and } \\
\text { advanced technologies }\end{array}$ \\
\hline $\begin{array}{l}\text { Millennium Cell } \\
\text { survey, } 2003\end{array}$ & U.S & Adults (18+) & 1,006 & $\begin{array}{l}9 \text { questions, closed- } \\
\text { end }\end{array}$ & $\begin{array}{l}\text { Preferences and requirements for hydrogen } \\
\text { fuel-powered vehicles; knowledge of } \\
\text { government subsidies for hydrogen } \\
\text { technologies }\end{array}$ \\
\hline
\end{tabular}


The surveys reviewed in this report have different audiences, objectives, formats, and methods of analysis. Hence, the results are not always consistent. Because the purpose of this literature review was to provide input to the survey methodology and design of the HFCIT Baseline Knowledge Assessment, some "lessons learned" are suggested.

- The public knows very little about hydrogen and fuel cell technologies (Sections 2.2, 2.6, 2.7).

- Although the public has very little knowledge about hydrogen, the public is accepting of the potential for hydrogen use (Sections 2.2, 2.5, 2.7).

- The public considers safety the most important characteristic to consider for any new technology (Sections 2.2, 2.3, 2.7); persons who believe hydrogen would be a poor replacement fuel for gasoline and diesel give safety as the reason for their concern (Section 2.6).

- The public will purchase a new technology only if the cost is reasonable (Sections $2.2,2.4,2.5,2.6,2.7,3.4)$; availability of fuel and convenience of the technology are also important (Sections 2.6, 2.7).

- There is an apparent discrepancy among surveys based on the type of survey being conducted. Attitude surveys tend to follow an ideal philosophy; experimental and preference surveys tend to reflect actual purchasing intentions (Section 3.4).

- The U.S. public wants to decrease our nation's dependence on foreign oil (Sections 2.4, 2.6).

- Communication of hydrogen program goals with the public and high government officials has been poor (Section 2.1) and education of policy makers is important (Section 2.3).

- The education program should emphasize environmental advantages, energy independence, and technology for the future (Sections 2.3, 2.4, 3.1).

- Opinions on new technologies differ based on educational levels, social backgrounds, and geographic locations (Section 2.5).

- The U.S. public considers electricity/batteries as the best replacement for gasoline and diesel (Section 2.6).

- Information about hydrogen and fuel cells is obtained primarily from the mass media (Sections 2.2, 2.5).

\subsection{CONCLUSIONS}

The purpose of the HFCIT surveys is, first, to assess the current state of awareness and understanding of hydrogen and fuel cell technologies and the hydrogen economy within four target populations in order to establish a baseline. In the surveys that addressed technical knowledge, the knowledge levels about hydrogen were very low. Therefore, Tests for knowledge (as differentiated from opinions) must be carefully crafted. Questions should be sufficiently basic to ensure that respondents understand the question. This level of understanding will differ across the four target populations.

Secondly, the same questions used in the initial HFCIT survey will be used again three years hence, to measure changes in the baseline of knowledge and opinions. This set of 
surveys is unique in this respect. The questions must, therefore, be relevant outside of any time context, and they must be sufficiently difficult to allow for measurable improvement in performance with them.

Surveys with a limited number of respondents can use open-ended responses. Because open-ended questions are difficult to analyze statistically for large populations, this format does not lend itself to the HFCIT surveys. In addition, the open-ended question format would be a problem with the HFCIT surveys because they will be replicated in the future in order to compare responses over time.

This literature review will be useful in helping to design the surveys to accomplish the objectives of HFCIT for each target population.

\subsubsection{General Public}

The European Commission Accept H2, Rocky Mountain Poll, European Commission Eurobarometer, transportation energy, and Millennium Cell surveys sought opinions from the general public. When questions on environmental issues were phrased to assess the importance of environmental issues and a dependence on imported oil, the public responded that it was very important to protect the environment and to reduce dependence on foreign oil. When asked to rank the importance of issues influencing a decision to buy, however, the most important issues were safety, cost, and convenience. The questions in the HFCIT survey need to be carefully crafted to ensure that this issue is addressed.

Because some regional differences were noted in one poll, the HFCIT survey should ensure that possible regional differences can be statistically analyzed.

Finally, polls agree that the public lacks knowledge about hydrogen and fuel cell technologies. In the transportation energy survey series, however, the polls indicate that the public's ability to name specific alternative-fuel vehicles increased between 20002001-2002. It is important to understand why the public is increasing its awareness of specific alternative vehicles without increasing its knowledge of the technologies used by these vehicles. While neither knowledge nor a lack of knowledge of hydrogen technologies correlates strongly with acceptance, acceptance is correlated with experience with the technology. It is important to verify this finding in the HFCIT survey. The best education plan may be a hands-on approach.

In addition, it is important to learn where the different populations of concern to HFCIT obtain information on energy and technologies. It is also important to identify who (i.e., which agencies or organizations) the public believes or trusts.

\subsubsection{Potential Large Users (Industry)}

The HTAP survey polled persons in industry and government. An area that showed a dichotomy in viewpoints concerned commercialization of hydrogen technologies. One 
opinion favored long-term renewable-based research and development, while the other favored rapid commercialization of fossil-based technologies. There was also a difference of opinion on the value of demonstration projects. The HFCIT survey of industries could pursue this dichotomy and could also investigate interest in areas for commercialization (e.g., vehicles, utilities). Industrial knowledge and opinions on international coordination, research and development funding assistance, and safety issues are needed. Finally, a knowledge assessment of industry's understanding of hydrogen products, storage, and infrastructure could be useful.

The Breakthrough Technologies survey included responses from individuals involved in fuel cell development. Although the respondents agreed that applications education is needed, they were unable to identify specific needs. It is possible that the HFCIT survey can be useful in identifying specific information needs and the depth of technical information needed.

The RKS surveys of businesses (Section 3.3.2) concluded that businesses that have experienced power outages and businesses that stress self-sufficiency are the most likely companies to purchase fuel cells for onsite generation capabilities. The HFCIT surveys could be used to validate and expand this finding.

\subsubsection{Students and Educators}

The European Commission Accept H2 survey included students. Students exhibited very little knowledge about hydrogen. The HFCIT educational surveys need to ensure that the knowledge questions on the survey are fairly basic in order to have some correct responses; however, they also need to be able to assess gains in knowledge and information.

The Breakthrough Technologies survey solicited opinions from academia. The basic message from this survey was that the education program should contain basic, simple messages. This finding reinforces the European Commissions Accept $\mathrm{H} 2$ results.

\subsubsection{State and Local Agencies}

The Breakthrough Technologies surveys solicited opinions of government personnel. Respondents to the survey considered policy makers and legislators as very important targets for an education program. There was no consensus of opinion about the content of the education program. One objective of the HFCIT survey of state and local agencies could be to determine the current knowledge level of the agency personnel and level of understanding of available programs, to inventory the current resources at the agencies, and to determine the level of interest in hydrogen technologies.

HTAP surveyed government personnel who were already involved in hydrogen energy or in areas that could be impacted by hydrogen energy in the future. It is assumed that none of these respondents were from state or local agencies. 


\subsubsection{HFCIT Surveys and Other Organizations}

As interest in hydrogen and fuel cell technologies increases, the HFCIT surveys will contribute to the overall understanding of how much each target group knows about hydrogen. Thus, the HFCIT surveys will be useful to other organizations, both in the United States and abroad, as they develop energy plans. 


\section{REFERENCES}

\section{PRIMARY SOURCES}

Breakthrough Technologies Institute, Survey Results - Fuel Cell Education Survey, conducted by Bill Frederick Communications, Palm Harbor, Florida, accessible via the FuelCell2000 library at http://www.fuelcells.org/biblio.htm , 2002.

European Commission, EUROBAROMETER - Energy: Issues, Options and Technologies, Science and Society, The European Opinion Research Group, http://europa.eu.int/comm/public_opinion/archives/eb/ebs_169.pdf , December 2002.

European Commission,The Acceptance of Hydrogen Technologies, study carried out by Matthias Altmann, Ludwig-Bölkow-Systemtechnik GmbH, Ottobrunn, Germany, and Cornelia Gräsel, Ludwig-Maximilians-Universität München Institute for Educational Psychology, München, Germany, www.hyweb.de/accepth2, September 1998.

Hydrogen Technology Advisory Panel (HTAP), Survey Report, May 4, 1998, available from http://www.eere.energy.gov/hydrogenandfuelcells/advisory_panels.html , May 1998.

Millennium Cell and U.S. Borax Inc., "Harris Poll Shows Americans’ Early Preferences and Requirements for Hydrogen Fuel-Powered Vehicles: Safety, Cost, and Vehicle Range Are Key Consumer Needs,” http://www.millenniumcell.com/cgibin/news.pl?function=detail\&id=06112003 , June 11, 2003.

Rocky Mountain Poll, "Reducing U.S. Dependency on Foreign Oil: 35 MPG Requirements and Emerging Hydrogen Fuel Technology Seen as Important Strategies,” Behavior Research Center, Inc., Phoenix, Arizona, Report 2002-IV14, http://www.brcpolls.com/pra02.htm , November 2002.

Transportation Energy Surveys:

Gurikova, Tatyana, Transportation Energy Survey Data Book 1.1, ORNL/SUB/024000008627/01, Oak Ridge National Laboratory, Oak Ridge, Tennessee, May 2002.

Steiner, Elyse, Consumer Views on Transportation and Energy, DRAFT, National Renewable Energy Laboratory, June 2003. 


\section{OTHER SOURCES}

Altmann, Matthias, Patrick Schmidt, Susana Mourato, and Tanya O'Garra, Analysis and Comparisons of Existing Studies, Research funded by the European Commission, Contract ENK5-CT-2002-80653, August 2003.

Altmann, Matthias, Ludwig-Bölkow-Systemtechnik GmbH, personal communication with Tykey Truett, ORNL, August 15, 2003.

Ballard News Release, "Ballard Power Systems, XCELLSIS, Chicago Transit Authority Conclude Successful Fuel Cell Bus Demonstration Project, http://www.ballard.com/pdfs/Pr000323_0.pdf, March 23, 2000.

California Fuel Cell Partnership, “Survey,” http://www.cafcp.org/cgilocal/survey/survey.cgi .

Fuel Cell Today, "Fuel Cell Market Survey: Portable Applications," http://www.fuelcelltoday.com/FuelCellToday/FCTFiles/FCTArticleFiles/Article 631_Portable2003.pdf, July 2, 2003.

Fuel Cell Today, "Fuel Cell Market Survey: Niche Transport Applications," http://www.fuelcelltoday.com/FuelCellToday/FCTFiles/FCTArticleFiles/Article 567_NicheTransport0303.pdf , March 5, 2003.

Fuel Cell Today, "Fuel Cell Market Survey: Light Duty Vehicles,” http://www.fuelcelltoday.com/FuelCellToday/FCTFiles/FCTArticleFiles/Article_ 546_MarketSurveyLightDutyVehicles.pdf , January 15, 2003.

Fuel Cell Today, "Fuel Cell Market Survey: Stationary Applications," http://www.fuelcelltoday.com/FuelCellToday/FCTFiles/FCTArticleFiles/Article 467_MarketSurveyStationaryApplications.pdf, May 22, 2002.

Fuel Cell Today, "Fuel Cell Market Survey: Buses,” http://www.fuelcelltoday.com/FuelCellToday/FCTFiles/FCTArticleFiles/Article 512_MarketSurveyFuelCellBuses0902.pdf, September 25, 2002.

Fuel Cells 2000, “Fuel Cell Library,” http://www.fuelcells.org/biblio.htm .

The Gallup Organization, "Poll Analyses, 11/27/2001, Americans Favor Alternative Energy Methods to Solve Shortages," http://www.gallup.com/subscription/?m=f\&c_id=10910 .

H2CARS.BIZ, “Polls: Hydrogen Values,” http://www.h2cars.biz/artman/publish/cat_index_20.shtml . 
Levin, Jamie, AC Transit, Oakland, California, personal communication with Tykey Truett, ORNL, October 16, 2003.

ORC International, "Detailed Tabulations of Caravan: New Alternative-Fueled Vehicles," Prepared for the National Renewable Energy Laboratory, Study 711069, February 2002.

PollingReport.com, “Environment,” http://www.pollingreport.com/enviro.htm .

Reichman, David J., RKS Research \& Consulting, personal communication with Tykey Truett, ORNL, August 4, 2003.

RKS Research \& Consulting, "Press Releases - Personal Power: More U.S. Homeowners Show Interest in On-site Options for Generating their Own Electricity,” http://www.rksresearch.com/press093002.html .

RKS Research \& Consulting, "Press Releases - New National Survey Shows Increasing Interest in On-site Power Generation Among Select Segments of U.S. Business," http://www.rksresearch.com/press073002.html .

Simmons, Timothy, Daniel Betts, Vernon Roan, and Paul Erickson, “A Preliminary Assessment of the Possible Acceptance of Fuel Cell Bus Technology by Current Fleet Vehicle Operators," SAE Technical Paper 2002-01-3057, presented at the International Truck and Bus Meeting and Exhibition, Detroit, Michigan, November 18-20, 2002.

Tang, Stephen S., Millennium Cell Inc., “Consumer Demand as a Driver for New Technology," presentation at the Hydrogen and Fuel Cells 2003 Conference and Trade Show, June 11, 2003.

U.S. Department of Energy, Hydrogen, Fuel Cells, and Infrastructure Technologies Program, "Safety, Codes \& Standards," http://www.eere.energy.gov/hydrogenandfuelcells/codes/, January 2003. 